\title{
The analysis of copper-iron metallic mixture by means of XRD and XRF
}

\author{
Halo Dalshad Omar ${ }^{1, a}$
}

${ }^{1}$ Soft Materials and Devices Laboratory, Department of Physics, Faculty of Science and Health,
Koya University Daniel Mitterrand Boulevard, Koya KOY45 AB64, Kurdistan Region - Iraq

aemail: halo.dalshad@koyauniversity.org

Keywords: Copper-Iron alloy, Crystallite size, Intensity, XRD analysis, XRF analysis

\begin{abstract}
The objective of the paper has been given on observations based on studies of the three samples of copper-iron $(\mathrm{Cu}-\mathrm{Fe})$ alloy have been prepared from $3 \mathrm{gm}$ mass of copper of $99.9 \%$ purity powder and adding $1 \mathrm{gm}$ weight of iron powder and adding $1.5 \mathrm{gm}$ weight of iron powder. A discussion about simple and low cost preparation of $\mathrm{Cu}-\mathrm{Fe}$ alloy by Mini Mill 2 Panalytical and preparation of the sample was rotating at $10 \mathrm{~min}$ and in case of grinding samples at high speed 300 rpm. Herzog press Panalytical used to produce pressed powder $\mathrm{Cu}-\mathrm{Fe}$ alloy. The characters of $\mathrm{Cu}-$ Fe particles are depending on their size, shape and chemical surroundings. X-Ray Diffraction (XRD) (Model: Panalytical Empyrean) study is most important tool used in powder materials science. For studied three samples the value of (111) plane has the highest value compared to other planes. The spectra obtained were analyzed using X-ray fluorescence (XRF) (Model: Rigaku-NEX $\mathrm{CG}$ ). From the spectra obtained, there were some elements to be present in the sample were $\mathrm{Cu}-\mathrm{Fe}$. The intensity of $\mathrm{Cu}$ pure is larger than impurity copper samples analysis by XRD and XRF. Also impurity affects the intensity, $(2 \theta)$ position and shape of the X-ray spectra.
\end{abstract}

\section{INTRODUCTION}

An alloying material in pure form is difficult and has a high cost [1]. In industrial metal production there is usually a need of fast analysis to choice of sample preparation. The processes of manufacturing powder metallurgy depend largely on the physical and chemical characteristics of the initial metal powders [2]. The characteristics of metal powders in turn depend upon the method used in producing these metal powders. The basic characteristics of metal powder are: chemical composition and purity, particle size and its distribution, particle shape. $\mathrm{Cu}-\mathrm{Fe}$ alloy powder is a measure of the powder ability to deform under applied pressure and is represented by pressure [3]. Copper is one of the most common alloy elements in the powder metallurgy field. The addition of iron powder to copper to increased mechanical strength and hardness of the $\mathrm{Fe} / \mathrm{Cu}$ sintered alloys [4] it calculated a grain size, a modifier or a hardener because the size of the lattice constant depends on the size of the ions [5]. The crystal structure of iron is body centered cubic (BCC) and copper is face centered cubic (FCC) [6]. X-Ray Diffraction (XRD) used to determine peak position was carried out using a Panalytical Empyrean. Operating at $45 \mathrm{kV}$ and $40 \mathrm{~mA}$, with a Cu X-ray tube $(\lambda=0.15406 \mathrm{~nm})$ equipped with a $1 \times 1 \mathrm{~mm}^{2}$ point focus and a Nickel filter on the direct beam path to absorb the $\mathrm{Cu} \mathrm{K} \mathrm{K}_{\beta}$ radiation [7]. The incident beam is collimated with a $1 \mathrm{~mm}$. Diameter collimator and focused on the sample mounted on a four-circle goniometer. X-ray fluorescence (XRF) is a very simple analytical technique; $\mathrm{X}$-rays excite atoms in a sample, which emit $\mathrm{X}$-rays at energies characteristic of each element. The process of detecting and analyzing the emitted X-rays is called " X-ray Fluorescence Analysis." In most cases the innermost K and L shells are involved in X-ray Fluorescence detection.

\section{COPPER-IRON MIXTURE PREPARATION}

Before grinding copper-iron metallic by (Model: Mini Mill 2 Panalytical) was cleaned the bowl with acetone for a specific time. The hardness of the grinding bowl used and of the grinding balls must be higher than of the $\mathrm{Cu}-\mathrm{Fe}$ used [7-8]. The grinding bowls and grinding balls of $\mathrm{Cu}-\mathrm{Fe}$ are resistance to acids with the exception of hydrofluoric acid. The chemical composition of copper- 
iron alloy is given in different amount iron powder such as $\mathrm{Cu}$ pure $(3 \mathrm{gm}), \mathrm{Cu}(1.5 \mathrm{gm}) / \mathrm{Fe}(1.5 \mathrm{gm})$ and $\mathrm{Cu}(3 \mathrm{gm}) / \mathrm{Fe}(1 \mathrm{gm})$. Impurity affects on the intensity, $(2 \theta)$ position and shape of the X-ray spectrum. In accordance with the application, the grinding time should be adapted of the bowl. Copper-iron metallic has investigated at $10 \mathrm{~min}$ and in the case of grinding of samples at high speed $300 \mathrm{rpm}$. (Model: Herzog press Panalytical) makes pressing pellets of various materials efficient and reproducible. Suited for $\mathrm{Cu}-\mathrm{Fe}$ alloy pressing applications, the hydraulic pump is operated for a pressing to 15 tons.

\section{X-RAY DIFFRACTION AND PARTICLE SIZE CALCULATION BY DEBYE- SCHERRER METHOD}

X-ray diffraction is one of the most important characterization tools used in solid state chemistry and materials science [9]. Diffraction pattern gives information on size and shape of the unit cell from peak positions and information on electron density inside the unit cell, namely where the atoms are located from peak intensities. It is the first step in diffraction pattern analysis [10-11]. To index a powder diffraction pattern of determining the peak positions, it is necessary to assign Miller indices (h $\mathrm{k} \mathrm{l}$ ) to each peak. X-ray diffraction patterns of $\mathrm{Cu}-\mathrm{Fe}$ alloy mixtures with different weight $\mathrm{Fe}$ are shown in figure. 1 with smaller atom radius of $\mathrm{Fe}(0.126 \AA)$ compared with that of $\mathrm{Cu}(0.128$ $\AA$ ) [12]. As shown in the table 1, it means crystallite size increased by added iron the mechanical alloying. Indicating that there is Fe peak at $2 \theta=45.1$ and 82.8 degree as shown in figure 1 . XRD analyses of the prepared sample of $\mathrm{Cu}-\mathrm{Fe}$ alloy metallic were done by a Panalytical Empyrean (Under $45 \mathrm{kV} / 40 \mathrm{~mA}$ - X-Ray, 2 $\theta / \theta$-Scanning mode). Data was taken for the $2 \theta$ range of 5 to 90 degrees with a step of 0.013 degree. Moreover, the high intense peak for $\mathrm{Cu}$ pure material is generally (111) reflection, which is observed in the samples.

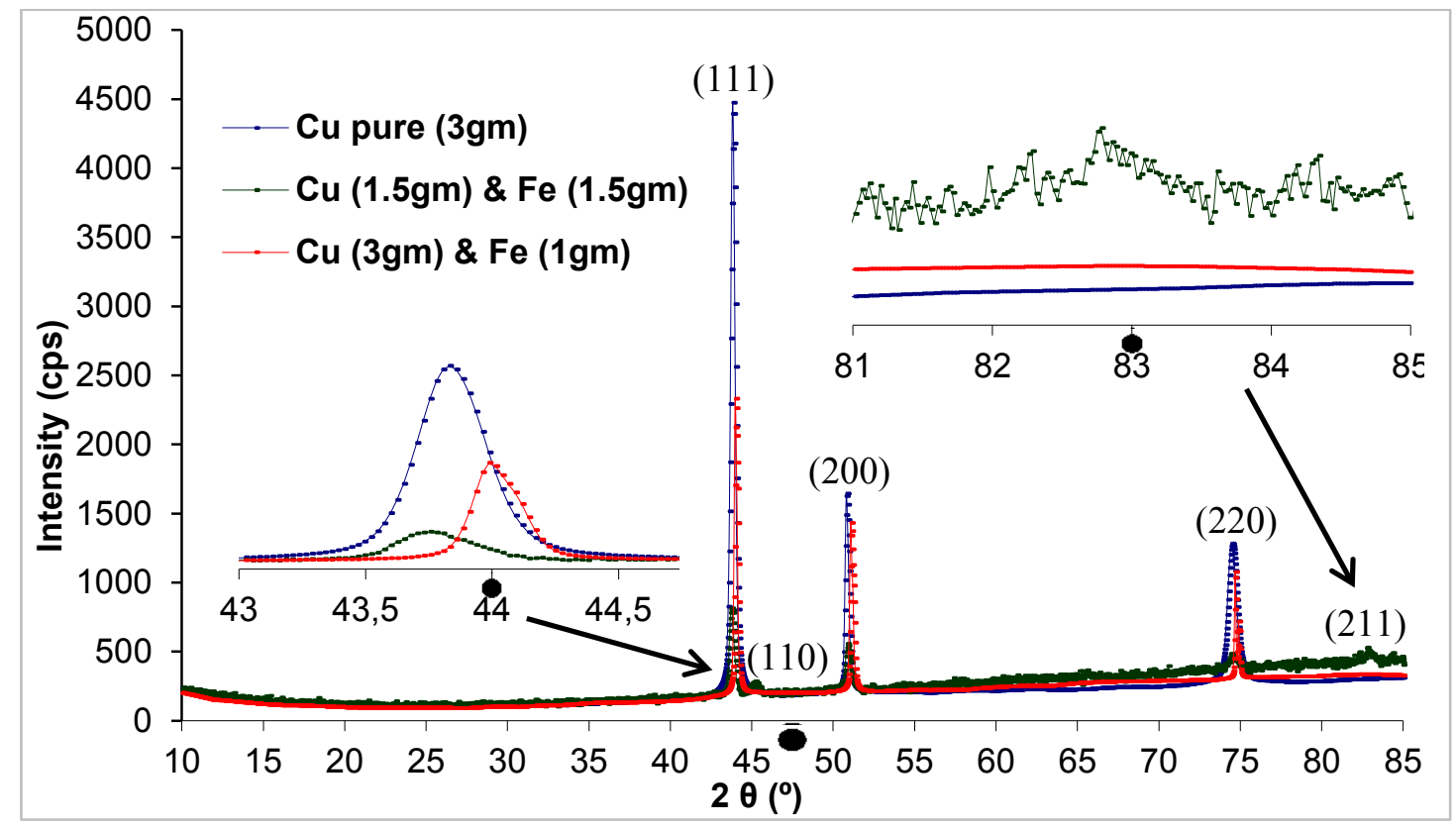

Figure.1. X-ray diffraction patterns of variation weight for $\mathrm{Cu}-\mathrm{Fe}$ alloy

The intensity of $\mathrm{Cu}$ pure has 4389.65 (cps) is larger than impurity copper samples, for $(\mathrm{Cu} 3 \mathrm{gm}+$ Fe $1 \mathrm{gm})$ the intensity was 2328.87 (cps) and ( $\mathrm{Cu} 1.5 \mathrm{gm}+\mathrm{Fe} 1.5 \mathrm{gm})$ has 777.66 (cps). Also the

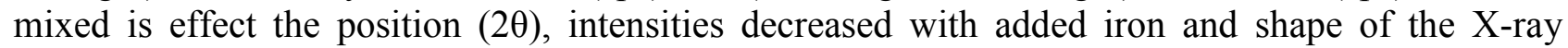
spectrum shown in the table (1) and figure (1). The Debye-Scherrer method uses a crystalline powder for $\mathrm{Cu}-\mathrm{Fe}$ alloy. The powder sample contains small single-crystals, so-called crystallites. A set of parallel lattice planes (hkl) in a crystallite leads to a constructive interference of reflected Xrays if its alignment fulfills the Bragg condition [13-14-15]. 


$$
n \lambda=2 d_{h k l} \sin \theta_{h k l}
$$

Where $\lambda$ - wave length of X-ray, d-interplaner spacing, $\theta$-diffraction angle, $\mathrm{n}=1,2$. 3 , The crystallite size can be found out by using the Scherrer's formula:

$$
D=\frac{0.9 \lambda}{\beta \cos \theta}
$$

Where ' $\lambda$ ' is wave length of X-Ray $(1.5406(\AA))$, ' $\beta$ ' is FWHM (full width at half maximum), ' $\theta$ ' is the degree of the diffraction peak and ' $\mathrm{D}$ ' is crystallite size. The chemical composition of copperiron alloy is given in different amount iron mixed with copper is given in the following table (1).

In the present diffraction pattern of XRD, five dominant peaks approximately $2 \theta$ equal $43.80^{\circ}$, $51.05^{\circ}, 74.86^{\circ}, 45.1^{\circ}$ and $82.8^{\circ}$ corresponding to the (111), (200), (220), (110) and (211) planes of $\mathrm{Cu}-\mathrm{Fe}$ alloy are seen with cubic crystal structure.

Table.1. Angular position, FWHM and crystallite size of the diffraction peaks for $\mathrm{Cu}-\mathrm{Fe}$ alloy

\begin{tabular}{|c|c|c|c|c|c|c|c|}
\hline $\begin{array}{c}\text { Samples and } \\
\text { weight }\end{array}$ & $2 \theta\left({ }^{\circ}\right)$ & $\begin{array}{c}\text { Peak- } \\
\text { element }\end{array}$ & $\begin{array}{l}\text { Intensity } \\
\text { (cps) }\end{array}$ & $\begin{array}{c}\text { FWHM } \\
\left({ }^{\circ}\right)\end{array}$ & d $(\AA)$ & $\begin{array}{c}\text { Crystallite } \\
\text { size }(\AA)\end{array}$ & $\begin{array}{c}\text { Miller } \\
\text { indices } \\
(\text { hkl) }\end{array}$ \\
\hline \multirow{3}{*}{$\begin{array}{c}\text { Copper pure } \\
\text { 3gm }\end{array}$} & 43.80 & $\mathrm{Cu}$ & 4389.65 & 0.2814 & 2.066 & 352.04 & (111) \\
\hline & 50.80 & $\mathrm{Cu}$ & 1624.14 & 0.1872 & 1.795 & 551.01 & $(200)$ \\
\hline & 74.42 & $\mathrm{Cu}$ & 1259.07 & 0.5610 & 1.273 & 161.64 & (220) \\
\hline \multirow{3}{*}{$\begin{array}{l}\text { Copper 3gm } \\
\text { and Iron 1gm }\end{array}$} & 43.980 & $\mathrm{Cu}$ & 2328.87 & 0.1535 & 2.058 & 691.27 & (111) \\
\hline & 51.071 & $\mathrm{Cu}$ & 1429.15 & 0.1535 & 1.788 & 711.58 & $(200)$ \\
\hline & 74.683 & $\mathrm{Cu}$ & 1030.43 & 0.1023 & 1.270 & 150.12 & $(220)$ \\
\hline \multirow{5}{*}{$\begin{array}{c}\text { Copper } 1.5 \mathrm{gm} \\
\text { and Iron } 1.5 \mathrm{gm}\end{array}$} & 43.719 & $\mathrm{Cu}$ & 777.66 & 0.2814 & 2.070 & 351.94 & (111) \\
\hline & 45.101 & $\mathrm{Fe}$ & 281.43 & 0.4093 & 2.010 & 239.78 & (110) \\
\hline & 50.820 & $\mathrm{Cu}$ & 486.65 & 0.1535 & 1.796 & 710.78 & (200) \\
\hline & 74.501 & $\mathrm{Cu}$ & 459.79 & 0.4093 & 1.273 & 278.88 & $(220)$ \\
\hline & 82.860 & $\mathrm{Fe}$ & 520.32 & 0.8187 & 1.149 & 146.48 & (211) \\
\hline
\end{tabular}
metallic by XRD.

\section{X-RAY FLUORESCENCE}

$\mathrm{X}$-Ray Fluorescence or secondary (XRF) is the phenomenon where a material is exposed to X-rays of high energy, and as the X-ray (or photon) strikes an atom (or a molecule) in the sample, energy is absorbed by the atom. The peaks in the spectrum correspond to the elements in the sample [16]. The number of X-ray in each peak is proportional to the number of atoms. The intensity or frequency of occurrence measured in counts per second, on the vertical axis and energy of the fluorescent signal, measured in kiloelectronvolts, across the horizontal axis shown in figure (2). 


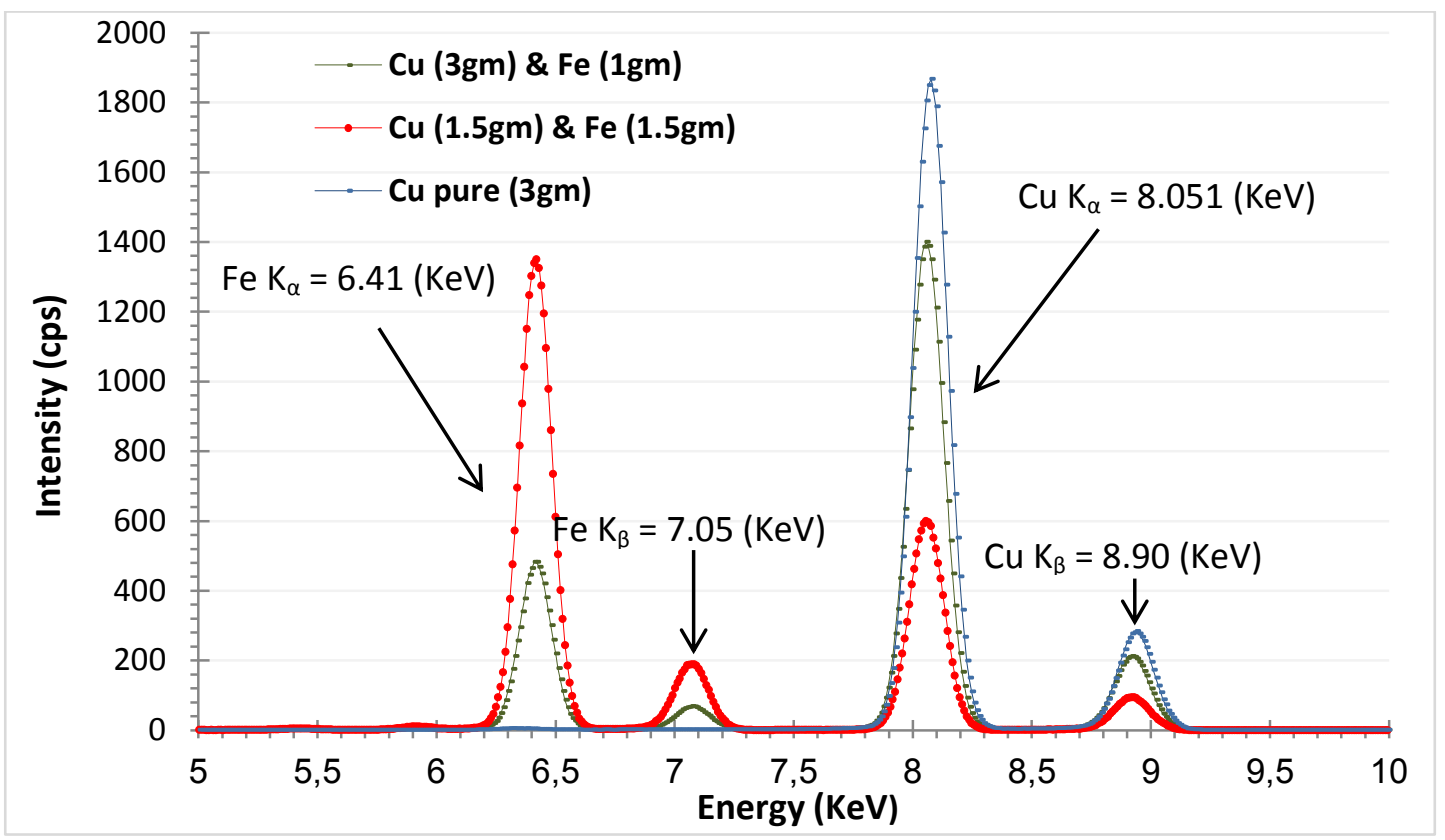

Figure.2. Show the measured energy spectrum \& variation of weight materials by XRF

The tube voltage and tube current can be set within $25 \mathrm{kV}$ and $1.0 \mathrm{~mA}$ respectively [1]. The measured intensity of single emission line depends on the energy spectrum and of exciting X-rays, on the efficiency of the detector and the geometry of source and sample. It also depends on the other elements in the sample because the intensity of $\mathrm{Cu} \mathrm{k}_{\alpha}$ pure was 1850.1 (cps) is larger than impurity copper samples, for $(\mathrm{Cu} 3 \mathrm{gm}+\mathrm{Fe} 1 \mathrm{gm})$ the intensity was 1385.5 (cps) and $(\mathrm{Cu} 1.5 \mathrm{gm}+$ Fe 1.5gm) was 600.29 (cps) shown in figure (2). $\mathrm{Cu} \mathrm{k}_{\alpha}$ has a strong peak at $8.051 \mathrm{keV}$ and $\mathrm{Cu} \mathrm{K}_{\beta}$ has a weak at $8.90 \mathrm{keV}$. The Fe was indicating that there is Fe at 6.41 and $7.05 \mathrm{keV}$ respectively as shown in the table (2).

Table.2. Variation of the samples of different intensities by XRF

\begin{tabular}{|c|c|c|c|}
\hline Sample / Weight & Peaks & Intensity (cps) & Energy $(\mathrm{KeV})$ \\
\hline \multirow[b]{2}{*}{$\mathrm{Cu}$ Pure (3gm) } & $\mathrm{k}_{\alpha}$ & $1850.1(\mathrm{Cu})$ & $8.051(\mathrm{Cu})$ \\
\hline & $\overline{\mathrm{K}_{\beta}}$ & $276.82(\mathrm{Cu})$ & $8.90(\mathrm{Cu})$ \\
\hline \multirow{4}{*}{$\begin{array}{c}\mathrm{Cu}(3 \mathrm{gm}) \& \mathrm{Fe} \\
(1 \mathrm{gm})\end{array}$} & \multirow[t]{2}{*}{$\mathrm{k}_{\alpha}$} & $481.72(\mathrm{Fe})$ & $6.41(\mathrm{Fe})$ \\
\hline & & $1385.5(\mathrm{Cu})$ & $8.051(\mathrm{Cu})$ \\
\hline & \multirow[t]{2}{*}{$\mathrm{K}_{\beta}$} & $41.74(\mathrm{Fe})$ & $7.05(\mathrm{Fe})$ \\
\hline & & $205.97(\mathrm{Cu})$ & $8.90(\mathrm{Cu})$ \\
\hline \multirow{4}{*}{$\begin{array}{c}\mathrm{Cu}(1.5 \mathrm{gm}) \& \mathrm{Fe} \\
(1.5 \mathrm{gm})\end{array}$} & \multirow[b]{2}{*}{$\mathrm{k}_{\alpha}$} & $1339.27(\mathrm{Fe})$ & $6.41(\mathrm{Fe})$ \\
\hline & & $600.29(\mathrm{Cu})$ & $8.051(\mathrm{Cu})$ \\
\hline & \multirow[b]{2}{*}{$\mathrm{K}_{\beta}$} & $186.98(\mathrm{Fe})$ & $7.05(\mathrm{Fe})$ \\
\hline & & $87.47(\mathrm{Cu})$ & $8.90(\mathrm{Cu})$ \\
\hline
\end{tabular}

\section{RESULTS AND DISCUSSION}

Five peaks have approximately $2 \theta$ values $43.80^{\circ}, 45.1^{\circ}, 51.05^{\circ}, 74.86^{\circ}$ and $82.8^{\circ}$ of corresponding to the (111), (110), (200), (220) and (211) planes of Cu-Fe alloy phase-standard powder diffraction card in shown figure 1.The XRD study confirms/indicates that the crystal structure of iron is body centered cubic (BCC) and copper is face centered cubic (FCC) by diffraction pattern. The measured intensity of single emission line depends on the energy spectrum and of exciting X-rays, on the efficiency of the detector and the geometry of source and sample. $\mathrm{Cu} \mathrm{k}_{\alpha}$ has a strong peak at 8.051 
$\mathrm{keV}$ and $\mathrm{Cu} \mathrm{K}_{\beta}$ has a weak at $8.90 \mathrm{keV}$. Iron was indicating that there is Fe at 6.41 and $7.05 \mathrm{keV}$ respectively as shown in figure (2).

\section{CONCLUSION}

Particle structure characteristics such as size and shape will also be dependent on production method. The high intense peak for $\mathrm{Cu}$ pure material is generally (111) reflection, which is observed in the samples by XRD analysis. The measured intensity of single emission line depends on the energy spectrum and the other elements in the sample. The intensity of $\mathrm{Cu}$ pure sample is larger than impurity ones analysis by XRD and XRF. Also impurity affects on the intensity, (20) position and shape of the X-ray spectrum. X-ray fluorescence intensities affected by particle size of different metal powders.

\section{Acknowledgements}

Author wishes to thank and supporting of this investigation by department of physics/ Faculty of Science and Health/University of Koya/ Kurdistan Iraq

\section{References}

[1] Halo Dalshad Omar, Surface analysis and roughness parameters of Copper Metallic, International Letters of Chemistry, Physics and Astronomy Vol. 57 (2015) pp66-71.

[2] A.sinha,"powder metallurgy", Ed., Dhanpat Ral\&Sons, Delhi, (1987).

[3] I.N.Svinolobova, P. N. Ostrik, and A. N. Kovzik, Properties of iron-copper masteralloypower, Vol.36, No.11-12,1997.

[4] Claudiu Nicolicescu, Daniel Zorila, Victor Nicoara, Marco Actis Grande, Marius Crivenu, Iulian Stefan, Research regarding the influence of copper powders on tensile strength of sintered steels, Advanced Engineering Forum Vol. 13 (2015)

[5] C. Biselli and D. G. Morris: Acta Metall. Mater. 42 (1994) 163-176.

[6] Jean-Claude Crivello, Tohru Nobuki and Toshiro Kuji, Thermal and Magnetic Properties of Mechanically Alloyed fcc Cu-Fe Supersaturated Solid Solutions, Materials, Transactions, Vol.49, No.3(2008)pp.527to531.

[7] Halo Dalshad Omar, To Investigation the Structure and Morphology of Iron Metallic by Difference Techniques,Department of Physics, School of Science, UniversityofKoya, J.Nano.Adv.Mat.3No.2,57-61,2015.

[8] M. Barzegar Vishlaghi, A. Ataie, Investigation on solid solubility and physical properties of $\mathrm{Cu}-\mathrm{Fe} / \mathrm{CNT}$ nano-composite prepared via mechanical alloying route, Powder Technology 268(2014) 102-109.

[9] Charles Kittel, Introduction to Solid State Physics(ISBN 047141526X) Wiley, 8thEdition,2004.

[10] N. Habubi, M. Hashim and A. Al-Yasiri, Baghdad Science Journal,7(2010) 1421.

[11] W. Peng, G. Cong, S. Qu and Z. Wang, Optical Materials ,29 (2006) 313.

[12] F.M. Lucas , B. Trindade , B.F.O. Costa , G. Le Caër, The Influence of PreMilling on the Microstructural Evolution During Mechanical Alloying of a Fe50Cu50 Alloy, Journal of Metastable and Nanocrystalline Materials eVolume 18 (2003)pp49-56.

[13] H.Wang, X. Lu, Y. Zhao and C. Wang, Materials Letters, 60 (2006) 2480.

[14] D.Awschalom,andJ.Kikkawa,Phys.Today,52(1999)33.

[15] B. D. Cullity and S. R. Stock, Elements of X-Ray Diffraction, Associate Professor of Metallurgyin, University of Notre Dame, 1978.

[16] Kenji Sakurai and Hiromi Eba, X-Ray Fluorescence Analysis with a Johansson-type Spectrometer, National Research Institute for Metals, 1-2-1, Sengen, Tsukuba, Ibaraki305-0047, Japan, 2 November1998. 